\title{
Two new cave-dwelling genera of short-tailed whip-scorpions from Brazil (Arachnida: Schizomida: Hubbardiidae)
}

\author{
Ricardo Pinto-da-Rocha', Renata Andrade² \& Jairo A. Moreno-González¹
}

\author{
'Departamento de Zoologia, Instituto de Biociências, Universidade de São Paulo, Caixa Postal 11461, \\ 05422-970, São Paulo, SP, Brazil. Email: ricrocha@usp.br, hansenochrus@gmail.com \\ 2Terradentro Estudos Ambientais. Caixa Postal 5367, 31011-970 Belo Horizonte, MG, Brazil.
}

\begin{abstract}
Two new genera of short-tailed whip-scorpions are described based on material from Brazilian iron ore and canga caves in the Carajás region, Pará, Brazil. Naderiore gen. nov. with a single species N. carajas sp. nov. and also monotypic Cangazomus gen. nov. (type species C. xikrin sp. nov.). The relationships of the two new genera with previously described genera are discussed. Naderiore most closely resembles Adisomus Cokendolpher \& Reddell, 2000, Piaroa Villarreal, Tourinho \& Giupponi, 2008 and Calima Moreno-González \& Villarreal, 2012, and can be distinguished from them by Dm 3 modified as macrosetae in the male flagellum. Cangazomus most closely resembles Naderiore, Adisomus Cokendolpher \& Reddell, 2000, and Piaroa Villarreal, Tourinho \& Giupponi, 2008. It differs from all of them by the presence of two pairs of ramified spermathecal lobes, each composed of a differentiated stalk and distoterminal ramified bulbs, chitinized arch without anterior branch and notched lateral tip, pedipalps unarmed and not sexually dimorphic, and the male flagellar setae $\mathrm{Dm}_{3}$ as a microsetae.

KEY WORDS. Canga cave, Cangazomus, Iron ore cave, Naderiore, neotropics, taxonomy.
\end{abstract}

The low diversity of Schizomida, 258 species according to Harvey (2007), especially in the Neotropical region, is not surprising in view of the small size of these arachnids (usually 2-7 mm of total length) and their cryptic habits, which are poorly known. Studies on South American schizomids have intensified in the 21st century. A review of schizomids recorded on this continent can be found in ARMAs (2010) where 34 described species in nine genera are cited. Additionally, the author mentions that there are at least 11 undescribed species and three undescribed genera in South America. Since then, two genera and 13 species have been described, most of them from Colombia (ARMas \& Delgado-Santa 2012a, b, Moreno-González \& Villarreal 2012, Villarreal \& García 2012, Delgado-Santa \& Armas 2013, Santos et al. 2013, Villarreal et al. 2014, Moreno-GonzÁlez et al. 2014), resulting in 47 described species on South America. This number is probably an underestimate of the true diversity of Schizomida, considering that the region of Manaus (Amazonas, Brazil), the only area reasonably well sampled, harbors seven species.

The following factors have contributed to the poor knowledge of this group in South America: first, there are only a few South American specialists in the group, and arachnologists from the Neotropics began to collect and describe new taxa from the region only in the $21^{\text {st }}$ century; second, Winkler and Kempson apparatus (but see ADIs et al. 1999) have not been widely used to collect arachnids in the Amazonian and Andean regions. As a result, suitable habitats there such as leaf litter, forest canopy and caves have been poorly sampled. In more recent years, Rolando Teruel and Luis de Armas have described a large number of new species from Central America, particularly from the Caribbean region. It is expected that the number of described species in South America will increase exponentially when the group receives more attention from researchers and is collected more intensively. This has already happened in other parts of the world during the last 40 years (HARvEY 2007: fig. 2). More research in this group is needed to clarify the relationships among the many monotypic genera that have been proposed and to generate phylogenetic hypotheses (see Moreno-González \& Villarreal 2012).

In this contribution, two new genera and two new species of short-tailed whip-scorpions (schizomids) are described based on material collected from Iron ore and Canga caves of Serra dos Carajás, Pará, Brazil, elevating the number of South American genera to 11 , and the number of described species to 49 . The relationships of the two new genera with those previously described are discussed.

\section{MATERIAL AND METHODS}

The type material is deposited in the Museu Paraense Emilio Goeldi (MPEG, curator A. B. Bonaldo) and in the Museu de Zoologia da Universidade de São Paulo (MZSP, curator R. 
Pinto-da-Rocha). Male and female flagellums were cleaned with detergent diluted in water, dried in acetone, and mounted on stubs with silver glue and sputter-coated (Balzer SCD 050) with gold. Stubs were photographed under a ZEISS DSM 940 Scanning Electron Microscope at the Centro de Microscopia Eletrônica of the Instituto de Biociencias (Universidade de São Paulo). The general nomenclature follows REDDELL \& COKENDOLPHER (1995), the setal group numbering follows LAWRENCE (1969). The terminology used for the chitinized arch of spermathecae follows MORENO-GONZÁLEZ et al. (2014). The flagellar setation follows HARveY (1992) modified by COKENDOLPHER \& REDDELL (1992), with the additions of VilLARREAL et al. (2014) and Moreno-González et al. (2014). Pedipalp setae follows Monjaraz-Ruedas \& Francke (2015). Abbreviations: (AB) anterior branch, (AMN) anteromedian notch, (AMP) anteromedian process, (DO) duct openings, (GOP) glandular openings, (IA) internal angle, (PB) posterior branch, (LT) lateral tip.

The illustrations of the chelicerae and spermathecae are based on photographs taken with a Zeiss Axioskop 50 microscope, integrated with the Carl Zeiss photo software Zen Lite, using the edition software Inkscape version 0.48.4 (www. inkscape.org). Z-axis photographs were created with a Leica M125 stereoscope with trinocular tube, integrated to the Leica software. The female genitalia were cleared with lactic acid 95\% for about 1-2 hours at room temperature. Measurements are given in millimeters ( $\mathrm{mm}$ ); total length excludes the flagellum.

\section{TAXONOMY}

\section{Hubbardiidae Cook, 1899 Hubbardiinae Cook, 1899 Naderiore gen. nov.} Figs. 1-3, 7-8, 12-17, 25

\section{urn:Isid:zoobank.org:act:118E66C6-9141-4B54-AAC7-F114F6F34CC1}

Type species. Naderiore carajas sp. nov., by monotypy.

Diagnosis. Naderiore most closely resembles Adisomus Cokendolpher \& Reddell, 2000, Piaroa Villarreal, Tourinho \& Giupponi, 2008 and Calima Moreno-González \& Villarreal, 2012, sharing with them the following characters: (1) four-segmented female flagellum, (2) male flagellum sub-rhomboidal shaped (only some Piaroa species), (3) absence of dorsal eminences on the male flagellum, (3) absence of gonopod in the spermathecae, (4) absence of posterodorsal abdominal process on the segment XII, and (5) absence of a single well developed accessory teeth in the chelicerae. Naderiore differs from all of them by the presence of two pairs of spermathecal lobes almost straight with distinct slightly marked terminal bulbs (Fig. 17), chitinized arch with an anteriorly notched LT (Fig. 17), male heteromorphic pedipalp patella armed with a ventral spur (Figs. 14-15), and the setae $\mathrm{Dm}_{3}$ modified as macrosetae on the male flagellum (Fig. 1). It may also be differentiated from Calima by the presence of chitinized arch in the spermathecae (Fig. 17) and $\mathrm{Vm}_{2}$ in both sexes flagella (Figs. 1-3, 7-8).
Etymology. "Naderiore" is a noun from Carajás indigenous people that means "brother". Gender masculine.

Remarks. A significant character of the genus is the presence of $\mathrm{Dm}_{3}$ modified as macrosetae in the male flagellum (Fig. 1), a unique condition among the Neotropical species of Hubbardiinae.

\section{Naderiore carajas sp. nov.}

Figs. 1-3, 7-8, 12-17, 25

\section{urn:Isid:zoobank.org:act:8BFC43FA-C4CA-486D-8BE5-2407755F58AC}

Diagnosis. Total length 3.7-3.9 mm (flagellum not included). Without eyespots. Male abdomen not elongated, without posterodorsal abdominal process on segment XII. Male flagellum rhomboidal 1.6 times longer than wide, and 5 times longer than pedicel length (Figs. 1-3). Spermathecae with two pairs of lobes, whose distal circular bulbs are slightly marked and roughly so thick as the stalk, medial lobes shorter than lateral ones, both with numerous duct openings over surface (Fig. 17); chitinized arch with $\mathrm{AB}$ and $\mathrm{PB}$ incomplete, IA rounded and LT sharp with an anterior notch (Fig. 17).

Description. Male holotype (homeomorphic). Coloration (in ethanol); general dorsal coloration pattern light brownishorange (Fig. 25); pedipalps, chelicerae, leg I and propeltidium slightly darker. Prosoma. Propeltidium long $(1.2 \mathrm{~mm})$, anterior process with only one seta followed by three pairs of dorso-submedian setae. Eyespot absent. Anterior sternum with $11(9+2)$ setae; posterior sternum with 7 setae. Metapeltidium entire. Pedipalp (Fig. 14). Trochanter with mesal spur, with an anteriorly projected sharp frontal process; femur without spurs; patella without a ventromesal curved spur; tibia without spurs. Femur, ectal surface with four setae near the ventral margin (Fe1, Fe2, Fv1 and Fv2). Chelicerae (Fig. 16). Fixed finger (Fig. 16: bottom) with two small teeth between two large outer teeth. Movable finger (Fig. 16: top): serrula composed of 18 hyaline teeth; guard tooth present, lamella present, accessory tooth absent. Setae: $\mathrm{G} 1=3$ setae, $\mathrm{G} 2=1, \mathrm{G} 3=4, \mathrm{G} 4=2, \mathrm{G} 5=8, \mathrm{G} 6=1$; setae $\mathrm{G} 1$ with spicules on their base. Opisthosoma. Tergite I with two pairs and tergite II with three pairs of anterior microsetae. Tergites I-VII each with one pair of dorso-submedian setae; VIII-IX each with one pair of dorso-submedian setae and one pair of distolateral setae; $\mathrm{X}$-XI narrow, each with one pair of lateral setae and five ventral setae; XII with one pair of dorso-median setae, two pairs of lateral and four pairs of ventral setae. Segments X-XII not elongated. Posterodorsal abdominal process of segment XII absent. Legs: anterior dorsal margin of femur IV produced at about 90 degrees angle, about three times as long as high. Flagellum (Figs. 1-3). Dorsoventrally flattened, bulb sub-rhomboidal, 1.6 times longer than wide, with short pedicel (1/5 total length). Setation: $\mathrm{Vm}_{1}$ at same level of $\mathrm{Vm}_{2}$, but distal to $\mathrm{Dm}_{1}$; pair $\mathrm{Dl}_{1}$ (microsetae) proximal to $\mathrm{Vm}_{1}$; pair $\mathrm{Vm}_{4}$ proximal to $\mathrm{Dl}_{2}$ level; pair $\mathrm{Dm}_{3}$ between $\mathrm{Dm}_{1}$ and $\mathrm{Dl}_{3} ; \mathrm{Dl}_{3}$ positioned slightly distal to $\mathrm{Vl}_{1} ; \mathrm{Vm}_{5}$ proximal to $\mathrm{Dm}_{4}$ level, closer to $\mathrm{Vl}_{1}$ than to $\mathrm{Vl}_{2} ; \mathrm{Vl}_{2}$ proximal to $\mathrm{Dl}_{3}$ level, and distal to $\mathrm{Dm}_{4}$ level. Setae pair $\mathrm{Dm}_{3}$ modified as macrosetae. With distolateral microsetae patches composed of four microsetae 

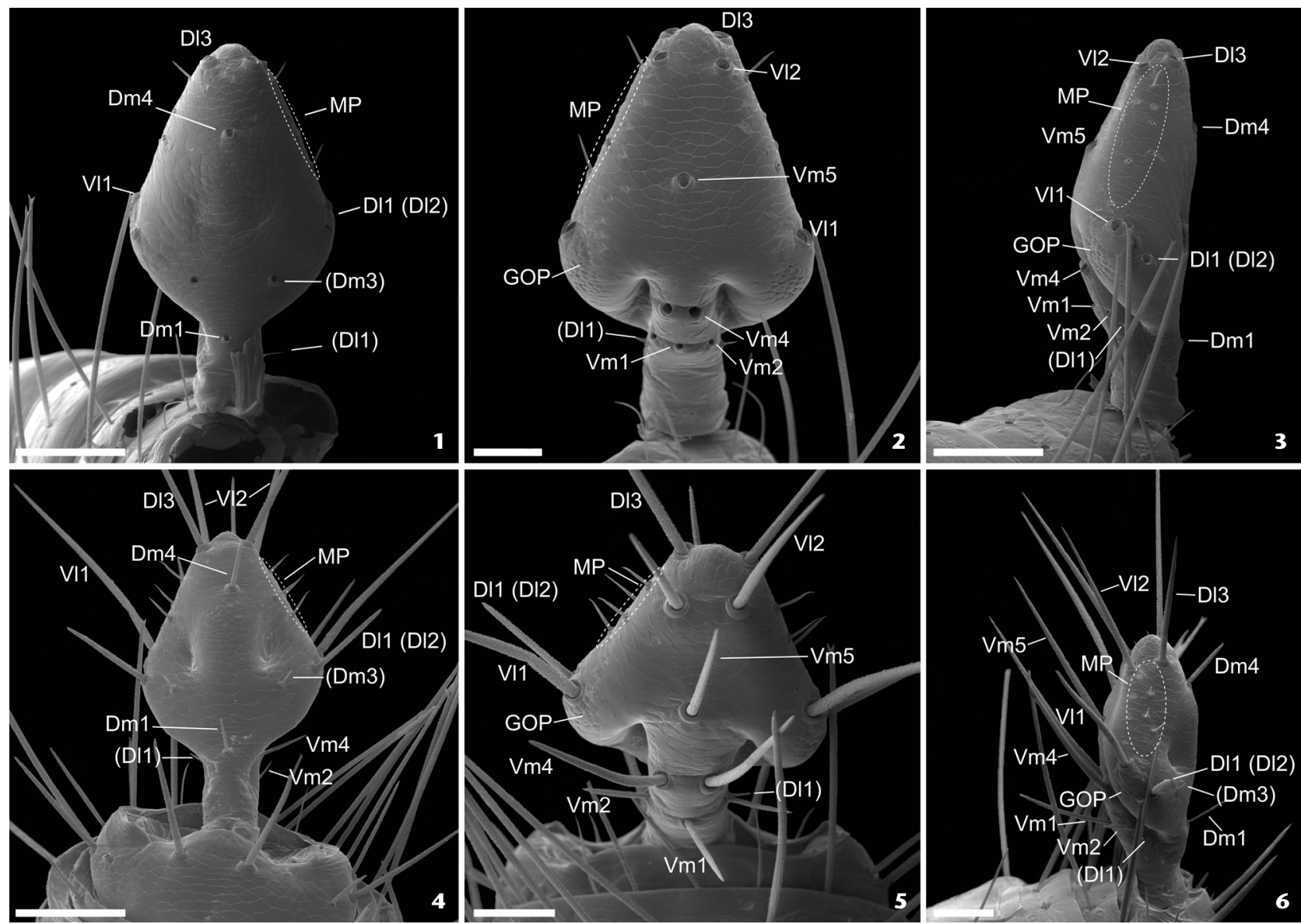

Figures 1-6. Male flagellum. Naderiore carajas gen. nov., sp. nov.: (1) dorsal; (2) ventral; (3) lateral. Cangazomus xikrin gen. nov., sp. nov.: (4) dorsal; (5) ventral; (6) lateral. Scale bars: $1,3-4=0.1 ; 2,5-6=0.05 \mathrm{~mm}$. Note: the setae named in parentheses correspond to the nomenclature of the flagellar setation proposed by Villarreal et al. (2014) and Moreno-González et al. (2014).

from the same level of $\mathrm{Vm}_{5}$ to slightly anterior to $\mathrm{Vl}_{2}$. With one pair of shallow dorso-submedian depressions at same level of $\mathrm{Dl}_{2}$, located at approximately half of the flagellum length, without any dorsal swelling. With several glandular openings (GOP) (see Figs. 12-13) and many grooves radiating from a central pore (see SANTOS \& PinTo-DA-Rocha 2009) on lateral and dorso-subapical regions; with several pores (without radiating striated grooves) on central ventral region.

Measurements (MZSP-65721). Pedipalp: trochanter 0.50; femur 0.62 ; patella 0.59 ; tibia 0.55 ; tarsus 0.25 ; total 2.37 . Leg I: trochanter 0.33; femur 1.19; patella 1.45; tibia 1.01; basitarsus 0.36; telotarsus 0.60; total 4.94. Leg II: 0.20; 0.93; 0.53; 0.55; $0.50 ; 0.42 ; 3.13$. Leg III: $0.23 ; 0.72 ; 0.30 ; 0.35 ; 0.56 ; 0.44 ; 2.60$. Leg IV: $0.30 ; 1.18 ; 0.56 ; 0.81 ; 0.72 ; 0.46 ; 4.03$. Total length: 4.00 . Propeltidium 1.25 long. Prosoma: 1.56 long. Opisthosoma: 2.20 long (flagellum excluded). Flagellum 0.41 long/0.15 wide.

Variation (male paratypes). Propeltidium 1.02-1.47 long; femur I 1.08-1.25; patella I 1.15-1.90 long; femur IV 1.02-1.35,
2.3-4.3 longer than wide. Anterior sternum 11-13 (9+2 to $11+2)$ setae. Paratypes with one or two setae on anterior process, a variation hitherto unreported in Hubbardiinae. Ventrally, patella with discrete (like females) to pronounced knob in heteromorphic males (Fig. 15) (MZSP-68883, MZSP-68907, MZSP-68871).

Female paratype (MZSP-65722). Coloration (in ethanol) and setation as in male except for: pedipalpal trochanter rounded, without frontal process, not projected anteriorly. Pedipalp patella without a ventral spur. Anterior sternum with $13(11+2)$ setae, posterior sternum with 5 setae. Propeltidium with two setae on the anterior process, both located near each other at the same level. Flagellum (Figs. 7-8) four-segmented. Segment II with $\mathrm{Dm}_{1}, \mathrm{Vm}_{1}$, and $\mathrm{Vm}_{2}$, all at the same level. Segment III with $\mathrm{Dm}_{3}$ (microsetae) proximal to $\mathrm{Vm}_{4}$. Segment IV with $\mathrm{Vl}_{1}$ at same level of $\mathrm{Vm}_{5}$ and $\mathrm{Dl}_{1} ; \mathrm{Dm}_{4}$ between $\mathrm{Dl}_{1}$ and $\mathrm{Dl}_{3} ; \mathrm{Vl}_{2}$ proximal to $\mathrm{Dl}_{3}$ and distal to $\mathrm{Dm}_{4} ; \mathrm{Dl}_{4}$ (microsetae) proximal to $\mathrm{Dl}_{3}$ and slight distal to above $\mathrm{Vl}_{2}$, between the level of $\mathrm{Dm}_{4}$ and $\mathrm{Dl}_{3}$. Apex of the flagellum with several glandular openings appearing as many grooves radiating 

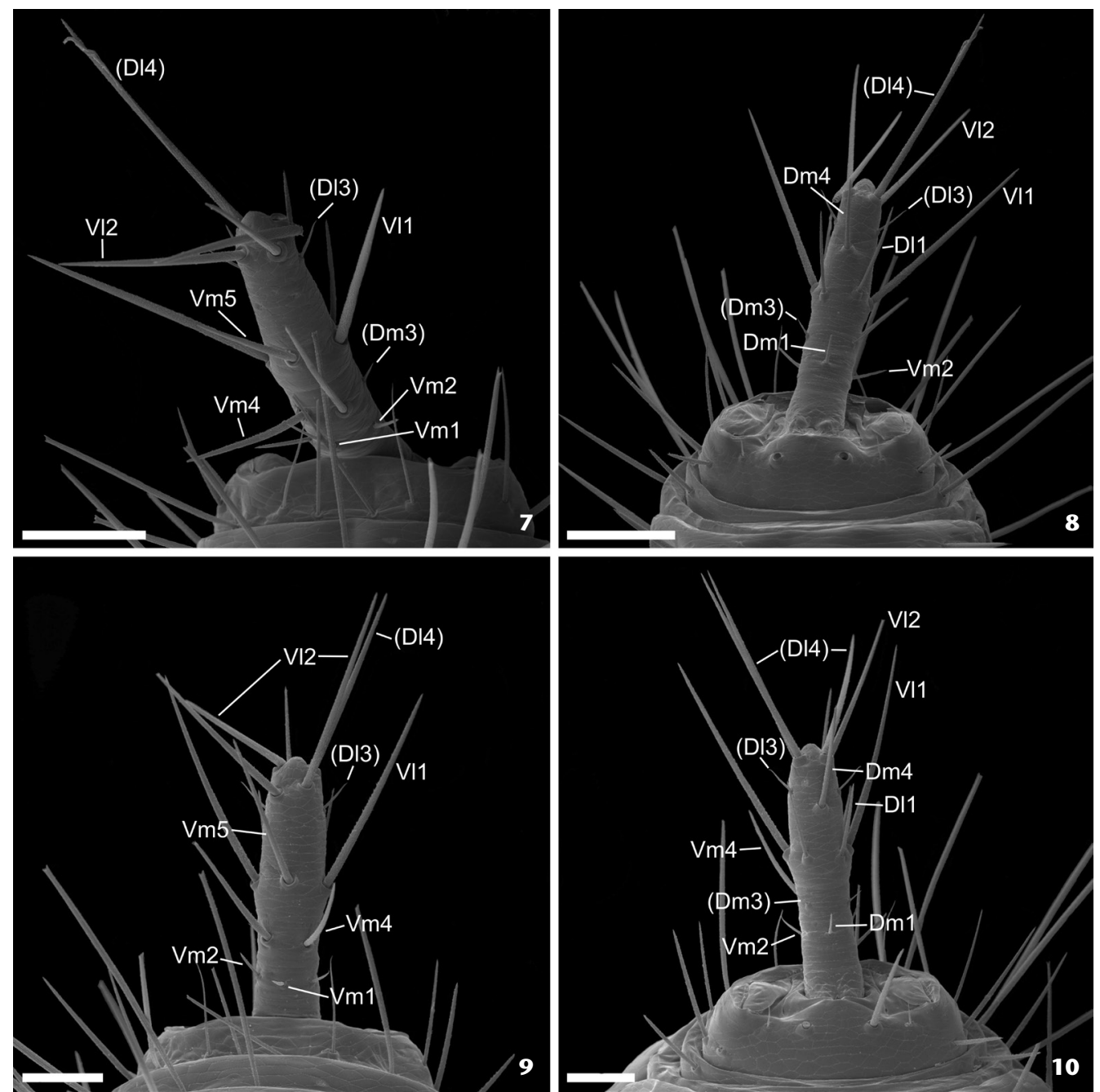

Figures 7-10. Female flagellum. Naderiore carajas gen. nov., sp. nov.: (7) ventral; (8) dorsal. Cangazomus xikrin gen. nov., sp. nov.: (9) dorsal; (10) ventral. Scale bar: $0.05 \mathrm{~mm}$. Note: The setae named in parentheses correspond to the nomenclature of the flagellar setation proposed by Villarreal et al. (2014) and Moreno-González et al. (2014).

from a central pore. Spermathecae (Fig. 17) consist of two pairs of almost straight lobes, with their apex anteriorly directed, whose distal circular bulbs are slightly marked and roughly so thick as the stalk; median lobes slightly thinner and shorter than lateral ones, both with cylindrical stalks covered with numerous DO over surface. Chitinized arch incomplete, $\mathrm{AB}$ and $\mathrm{PB}$ open, LT sharp and short with an anterior notch, IA rounded, without AMN and AMP.

Measurements (MZSP-68883). Pedipalp: trochanter 0.65; femur 0.50; patella 0.50; tibia 0.45 ; tarsus 0.25 ; total 2.35. Leg I: trochanter 0.30; femur 1.12; patella 1.27; tibia 0.95; basitarsus 0.32 ; telotarsus 0.50 ; total 4.40 . Leg II: 0.27 ; 0.80 ; 0.67; 0.47 ; $0.42 ; 0.62 ; 3.27$. Leg III: $0.22 ; 0.80 ; 0.45 ; 0.50 ; 0.45 ; 0.4 ; 2.87$. Leg IV: $0.27 ; 1.15 ; 0.50 ; 0.75 ; 0.65 ; 0.52 ; 3.85$. Total length: 3.65 . Propeltidium: 1.02 long. Prosoma: 1.32 long. Opisthosoma: 2.32 long (flagellum excluded). Flagellum 0.32 long.
Variation (females). Propeltidium 1.16-1.20 long; femur I 1.075; patella I 1.21-1.23 long; femur IV 1.00-1.03, 2.28-2.44 longer than wide. With one or two setae on anterior process.

Type material: Male holotype (Gruta S11D-33; 6²4'41"S $50^{\circ} 20^{\prime} 38^{\prime \prime}$ W), Floresta Nacional de Carajás, Canaã dos Carajás, Pará, Brazil, R. Andrade leg., 23.viii-02.ix.2007 (MZSP-65721). Paratypes: Floresta Nacional de Carajás, Parauapebas, Pará, Brazil: (Gruta N1-75), 2007, leg. R. Andrade, 1 female (MZSP-65722); idem, (Gruta N4WS-04; 604'23"S 50¹1'44"W), 10-19.v.2011, leg. R. Andrade, 1 male (MZSP-65723); idem, (Gruta N4WS-08, $\left.6^{\circ} 05^{\prime} 23^{\prime \prime} \mathrm{S} 50^{\circ} 11^{\prime} 42^{\prime \prime} \mathrm{W}\right), 10-19 . v .2011$, leg. R. Andrade, 1 female (MZSP-65724); idem, (Gruta N4WS-32, 604'05"S 50¹1'33"W), 18.xi-01.xii.2010, leg. R. Andrade, 1 male (MZSP-65725); idem, (Gruta N4WS-75, 604'29"S 50¹1'23"W) 18.xi-01.xii.2010, leg. R. Andrade, 2 males (MZSP-65726); idem, (Gruta N4WS- 

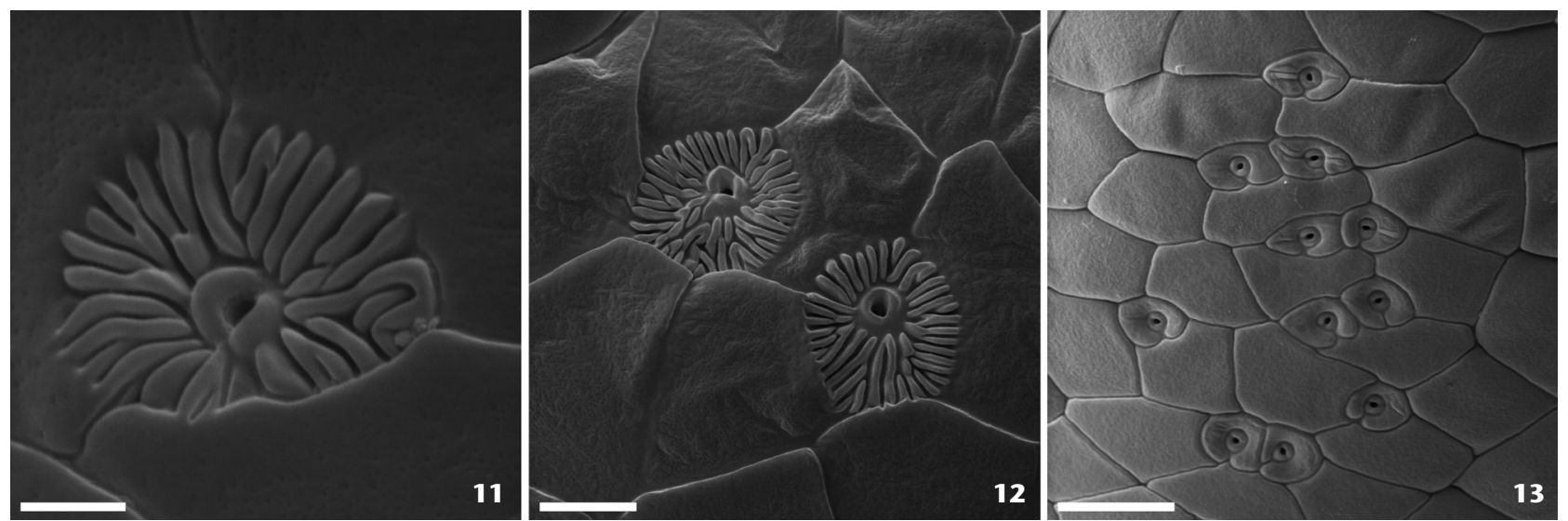

Figures 11-13. Glandular pores: (11) Cangazomus xikrin gen. nov., sp. nov.; (12-13) Naderiore carajas gen. nov., sp. nov. Scale bars: 11 = $0.002,12=0.005,13=0.01 \mathrm{~mm}$.

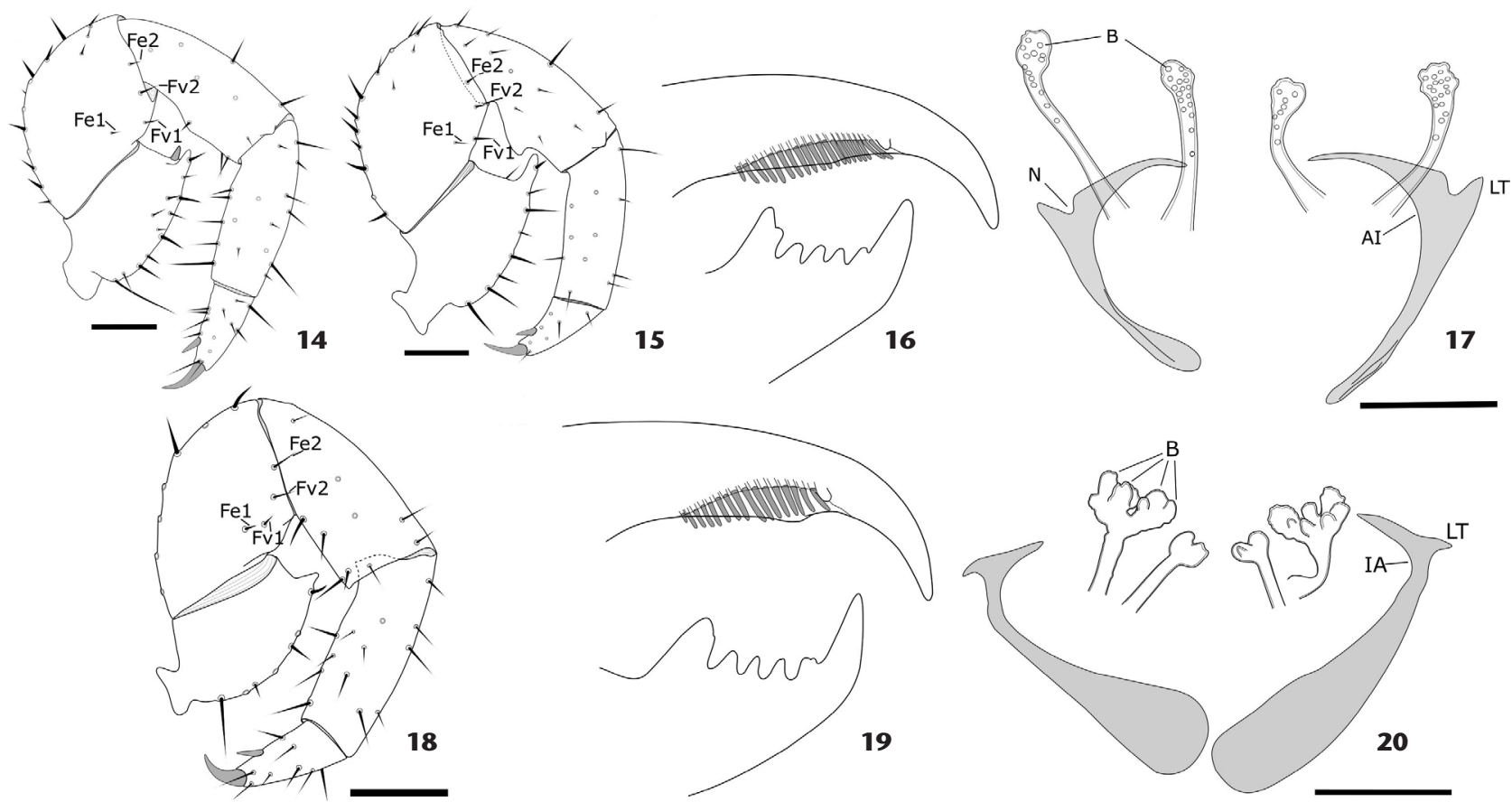

Figures 14-20. Pedipalp, chelicerae and spermathecae: (14-17) Naderiore carajas gen. nov., sp. nov.: (14) Male homeomorphic pedipalp (holotype); (15) Male heteromorphic pedipalp, paratype MZSP-68883; (16) Male chelicerae, holotype: top-movable finger, bottom-fixed finger; (17) female paratype spermathecae, MZSP-65724; (18-20) Cangazomus xikrin gen. nov., sp. nov.: (18) male pedipalp, holotype; (19) male chelicerae, holotype: top-movable finger, bottom-fixed finger; (20) female paratype spermathecae. Scale bars: 14-15, 18 = $0.20 \mathrm{~mm} ; 17,20=0.05 \mathrm{~mm}$. (Fe1) Femur ectal 1, (Fe2) femur ectal 2, (Fv1) femur ventral 1, (Fv2) femur ventral 2.

75; 604'28.7"S 50¹1'23.1”W), 18.ix-01.xii.10, leg. R. Andrade et al., 2 males (MZUSP-69601); idem, (N3-037; 602'46.4"S $\left.50^{\circ} 13^{\prime} 15.2^{\prime \prime} \mathrm{W}\right), 05-17 / \mathrm{III} / 2013$, leg. F. V. Freitas et al., 1 male (MZSP-68904); idem, (N3-037; 602'46.4"S 50¹3'15.2”W), 5-17. III.2013, leg. F. V. Freitas et al., 2 males (MZSP-68871); idem, (N3-047; 602'27.9”S 50¹3'41.7”W), 03-17/IV/2013, leg. F. V.
Freitas et al., 1 male (MZSP-68874); idem, (N3-074; 602'36.6"S $\left.50^{\circ} 13^{\prime} 51.0^{\prime \prime} \mathrm{W}\right), 02-23 / 08 / 2013$, leg. F. V. Freitas et al., 2 males (MZSP-68907); idem, (N3-074; 602'36.6"S 50¹3'51.0”W), 5-17/III/2013, leg. F. V. Freitas et al., 1 male, 1 female (MZSP68883). Floresta Nacional de Carajás, Canaã dos Carajás, Pará, Brazil: (Gruta S11-23, 6²5'25"S 50¹8'00”W), 24.ii-4.iii.2010, 
leg. R. Andrade, 1 male (MZSP-65728); idem, (Gruta S11D-116, $\left.6^{\circ} 25^{\prime} 19^{\prime \prime} \mathrm{S} 50^{\circ} 19^{\prime} 00^{\prime \prime} \mathrm{W}\right), 14-19 . x i i .2011$, leg. R. Andrade, 1 male (MZSP-65731).

Etymology. Named after the Carajás Formation, located in northern South America. The Carajás Formation is a banded iron-formation (BIF) that contains a large number of small iron ore and canga caves where the specimens were collected. The name is treated as a noun in apposition.

\section{Cangazomus gen. nov.}

Figs. 4-6, 9-11, 18-20, 26

urn:Isid:zoobank.org:act:6D708F82-68AB-4E75-BF57-53F4BB43BEA6

Type species. Cangazomus xikrin sp. nov., by monotypy.

Diagnosis. Cangazomus gen. nov. most closely resembles Naderiore gen. nov., Adisomus Cokendolpher \& Reddell, 2000, and Piaroa Villarreal, Tourinho \& Giupponi, 2008, sharing with them the following characters: (1) four-segmented female flagellum, (2) male flagellum sub-rhomboidal shaped (only some Piaroa species), (3) absence of dorsal eminences on the male flagellum, (3) absence of gonopod in the spermathecae, (4) presence of chitinized arch in the spermathecae, (5) absence of posterodorsal abdominal process on the segment XII, and (6) absence of a single well-developed accessory teeth in the chelicerae. Cangazomus differs from all of them by the presence of two pairs of ramified spermathecal lobes, each composed of a differentiated stalk and distoterminal ramified bulbs (Fig. 20), chitinized arch without $\mathrm{AB}$ and notched LT (Fig. 20), pedipalps unarmed and not sexually dimorphic (Fig. 18), and the male flagellar setae $\mathrm{Dm}_{3}$ as microsetae (Figs. 4-6).

Etymology. In reference to the canga, ferruginous breccias that covers the banded iron formation (BIF), where is located the cave from the type locality, and zomus, part of the name Schizomus. Gender masculine.

Remarks. The spermathecal lobes with ramified bulbs displayed by Cangazomus xikrin (Fig. 20) are a very novel condition among the Neotropical genera of Hubbardiidae; among the New World four-segmented genera, the North American genus Hubbardia Reddell \& Cokendolpher, 1995, and the Caribbean genus Luisarmasius Reddell \& Cokendolpher, 1995 share both an apparently similar spermathecal morphology, having spermathecae composed of more than three lobes in each side (REDDELL \& COKENDOLPHER 1995: 75, 81); however, the presence of multiple spermathecal lobes is a very distinct condition, compared with the presence of two pairs of lobes, each with ramified bulbs, exhibited by C. xikrin (Fig. 20). For this reason, we believe this character represent a synapomorphy for the genus.

\section{Cangazomus xikrin sp. nov.}

Figs. 4-6, 9-11, 18-20, 26

urn:Isid:zoobank.org:act:FBD1BCDD-CF9E-472C-AF7F-9A548419FF82

Diagnosis. Total length 2.85-3.20 mm (flagellum not included). Without eyesposts. Male abdomen not elongated, without posterodorsal abdominal process on segment XII. Male flagellum rhomboidal 1.8 times longer than wide, and 4 times longer than pedicel length (Figs. 4-6). Spermathecae with two pairs of ramified lobes, each composed of a differentiated stalk and distoterminal ramified bulbs, lateral lobes composed by at least four ramifications and medial ones with at least two ramifications (Fig. 20); chitinized arch without AB, PB incomplete, IA rounded and LT sharp without an anterior notch (Fig. 20).

Description. Male holotype. Coloration (in ethanol); general dorsal coloration pattern light brownish-orange (Fig. 26); pedipalps, chelicerae, and propeltidium slightly darker. Legs and venter much paler than dorsum. Prosoma. Propeltidium long $(1.17 \mathrm{~mm})$, anterior process with only one seta followed by three pairs of dorso-submedian setae. Eyespot absent. Anterior sternum with 14 setae $(12+2)$; posterior sternum with six setae. Metapeltidium entire. Pedipalp (Fig. 18). Trochanter with mesal spur, with a short frontal process; femur, patella and tibia without spurs. Femur, ectal surface with four setae near the ventral margin (Fe1, Fe2, Fv1 and Fv2).

Chelicerae (Fig. 15). Fixed finger (Fig. 15: bottom) with two smaller teeth between two large outer teeth. Movable finger (Fig. 15: top): serrula composed of 9 hyaline teeth; guard tooth present, lamella present, accessory tooth absent. Setae: G1 $=3$ setae, $\mathrm{G} 2=3, \mathrm{G} 3=3, \mathrm{G} 4=2$, G5 = 7, G6 = 1; setae $\mathrm{G} 1$ with spicules on their base. Opisthosoma. Tergite I with two pairs and tergite II with three pairs of anterior microsetae. Tergites I-VII each with one pair of dorso-submedian setae; VIII-IX each with one pair of dorso-submedian setae and one pair of distolateral setae; X-XI narrow, each with one pair of lateral setae and five ventral setae; XII with one pair of dorso-submedian setae, two pairs of lateral setae and four pairs of ventral setae. Segments X-XII not elongated. Posterodorsal abdominal process of segment XII absent. Legs: Anterior dorsal margin of femur IV produced at about 90 degrees angle, 2.1 times as long as high. Flagellum (Figs. 4-6). Dorsoventrally flattened, bulb sub-rhomboidal, 1.7 times longer than wide, with short pedicel (1/5 total length). Setation: $\mathrm{Vm}_{1}$ at same level of $\mathrm{Dm}_{1}$ and $\mathrm{Vm}_{2}$; pair $\mathrm{Dl}_{1}$ (microsetae) proximal to $\mathrm{Vm}_{1}$; pair $\mathrm{Vm}_{4}$ at same level of $\mathrm{Dl}_{2}$ level; pair $\mathrm{Dm}_{3}$ (microsetae) at same level of $\mathrm{Dl}_{2} ; \mathrm{Dl}_{3}$ positioned slightly distal to $\mathrm{Vl}_{2} ; \mathrm{Vm}_{5}$ proximal to $\mathrm{Dm}_{4}$ level, closer to $\mathrm{Vl}_{1}$ than to $\mathrm{Vl}_{2} ; \mathrm{Vl}_{2}$ proximal to $\mathrm{Dl}_{3}$ level, and distal to $\mathrm{Dm}_{4}$ level. With distolateral microsetae patches composed of three microsetae from the same level of $\mathrm{Vm}_{5}$ to slightly anterior to $\mathrm{Vl}_{2}$. With one pair of separated oval shaped and deep dorso-submedian depressions at same level of $\mathrm{Dl}_{2}$ (microsetae), located at approximately half of the flagellum length, without any dorsal swelling. With several glandular openings (GOP) (see Fig. 11) appearing as many grooves radiating from a central pore (see SANTOS \& PINTO-DA-Rocha 2009) on lateral and dorso-median to subapical region; without pores on central ventral region.

Measurements - (male holotype). Pedipalp: trochanter 0.37 ; femur 0.32 ; patella 0.52 ; tibia 0.37 ; tarsus 0.20 ; total 1.80 . Leg I: trochanter 0.25 ; femur 0.97 ; patella 1.12 ; tibia 0.80 ; basitarsus 0.27 ; telotarsus 0.45 ; total 3.87 . Leg II: $0.15 ; 0.47 ; 0.65$; $0.45 ; 0.35 ; 0.32 ; 2.40$. Leg III: $0.25 ; 0.60 ; 0.32 ; 0.40 ; 0.37 ; 0.35$; 

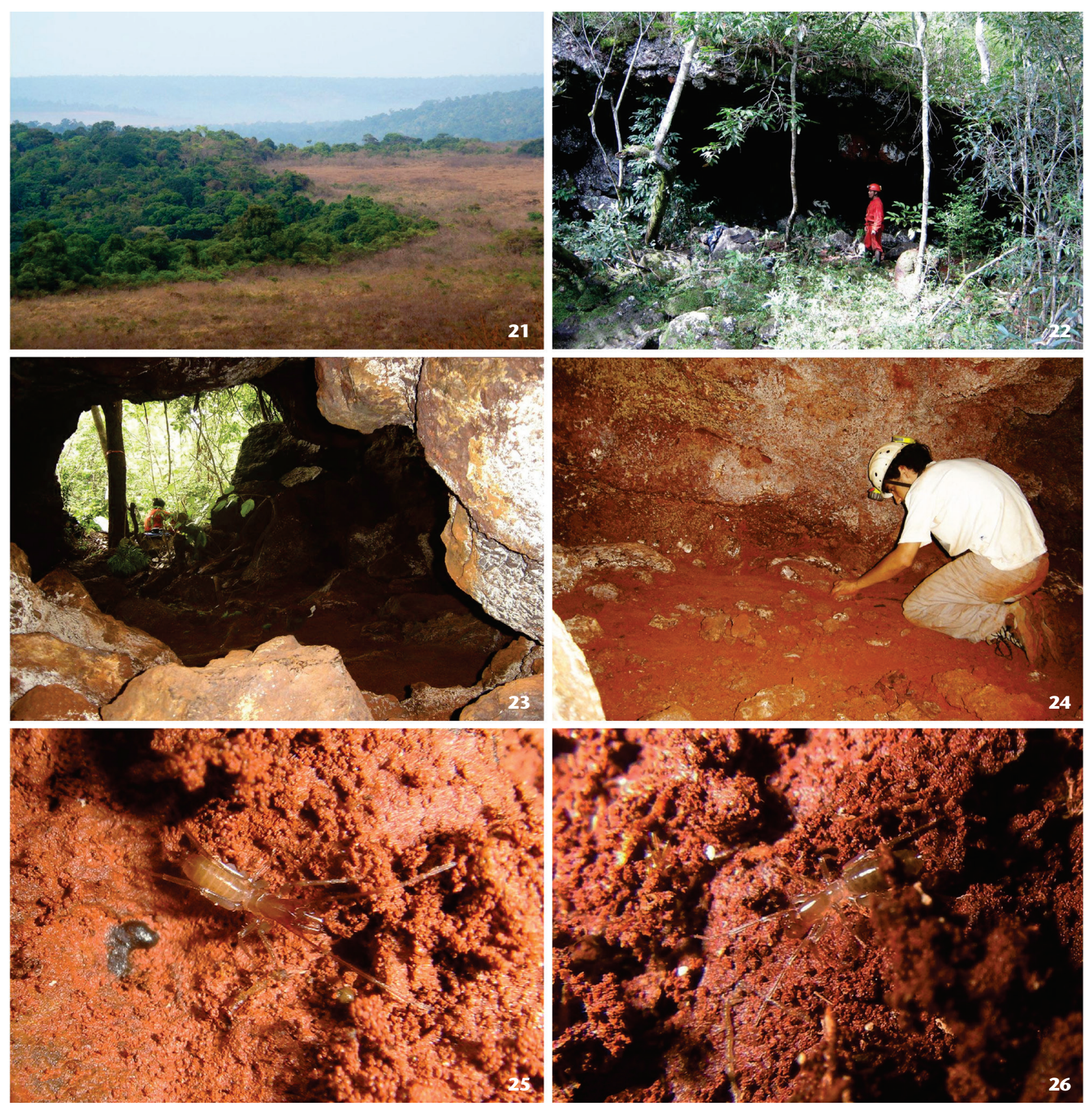

Figures 21-26. Photographs of habitat and live schizomids: (21) view of plateau at Carajás region, limit between canga and ombrophilous vegetation types; (22-23) entrance region of a canga cave; (24) invertebrate manual collecting on ground of the interior of a canga cave; (25) live male of Naderiore carajas gen. nov., sp. nov. on ground; (26) live female of Cangazomus xikrin gen. nov., sp. nov. on ground. Photos: (21-24) Renata de Andrade, (25) Igor Cizauskas, (26) Marcus Oliveira.

2.30. Leg IV: $0.25 ; 0.87 ; 0.42 ; 0.62 ; 0.57 ; 0.25 ; 3.10$. Total length: 2.12. Propeltidium: 1.17 long. Prosoma: 1.27 long. Opisthosoma: 1.57 long (flagellum excluded). Flagellum 0.32 long/0.17 wide. Variation (male paratypes). Propeltidium 0.81-0.94 long; femur I 0.75-0.93; patella I 0.91-1.13 long; femur IV 0.83-0.91, 2.2-2.4 longer than wide. Paratypes with one or two setae on anterior process; two small dorso-submedian depressions slightly deeper than holotype in some specimens. 
Female paratype (MZSP-65734): Coloration (in ethanol) and setation as in male except for: pedipalp trochanter rounded, without frontal process, not projected anteriorly. Flagellum (Figs. 9-10) four-segmented. Segment II with $\mathrm{Dm}_{1}, \mathrm{Vm}_{1}$, and $\mathrm{Vm}_{2}$, all at the same level. Segment III with $\mathrm{Dm}_{3}$ (microsetae) proximal to $\mathrm{Vm}_{4}$. Segment IV with $\mathrm{Vl}_{1}$ at same level of $\mathrm{Vm}_{5}$ and $\mathrm{Dl}_{1}$; $\mathrm{Dm}_{4}$ between $\mathrm{Dl}_{1}$ and $\mathrm{Dl}_{3} ; \mathrm{Vl}_{2}$ proximal to $\mathrm{Dl}_{3}$ and distal to $\mathrm{Dm}_{4} ; \mathrm{Dl}_{4}$ (microsetae) proximal to $\mathrm{Dl}_{3}$ and slightly distal to above $\mathrm{Vl}_{2}$, between the level of $\mathrm{Dm}_{4}$ and $\mathrm{Dl}_{3}$. Apex of the flagellum with several glandular openings appearing as many grooves radiating from a central pore. Spermathecae (Fig. 20) consist of two pairs of lobes, with their apex anteriorly directed and a distinguishable stalk; median lobes shorter than lateral ones, with one pair of terminal bulbs (bifurcation); lateral lobes with at least four to five bulbs; chitinized arch without $\mathrm{AB}, \mathrm{PB}$ incomplete, IA rounded and LT sharp and short, without an anterior notch (Fig. 20).

Measurements (MZSP-65734). Pedipalp: trochanter 0.31; femur 0.38; patella 0.35; tibia 0.30; tarsus 0.19; total 1.54. Leg I: trochanter 0.25 ; femur 0.84 ; patella 0.98 ; tibia 0.69 ; basitarsus 0.25 ; telotarsus 0.40 ; total 3.40 . Leg II: 0.13 ; $0.59 ; 0.34 ; 0.36$; 0.31-0.33; 0.31; 2.00. Leg III: $0.13 ; 0.50 ; 0.24 ; 0.25 ; 0.31 ; 0.31$; 1.70. Leg IV: $0.23 ; 0.85 ; 0.38 ; 0.56 ; 0.50 ; 0.38 ; 2.90$. Total length: 3.20. Propeltidium: 0.94 long. Prosoma: 1.20 long. Opisthosoma: 1.70 long (flagellum excluded). Flagellum 0.24 long.

Variation (female paratypes). Propeltidium 0.88-0.95 long; femur I 0.81-0.84; patella I 0.96-0.98 long; femur IV 0.84-0.85, 2.20-2.30 longer than wide.

Type material: Male holotype (Gruta N4E-72, 601'58"S 5009'14"W), Floresta Nacional de Carajás, Parauapebas, Pará, Brazil, 24-30.vii.2009, leg. R. Andrade (MZSP-65733). Paratypes: Floresta Nacional de Carajás, Parauapebas, Pará, Brazil: (Gruta N4E-72, 601'58"S 5009'14"W), Floresta Nacional de Carajás, Parauapebas, Pará, Brazil, 24-30.vii-2009, leg. R. Andrade, 1 male (MZSP-65732); idem, (Gruta N4E-72, 601'58"S $\left.50^{\circ} 09^{\prime} 14^{\prime \prime} \mathrm{W}\right), 19$. ii $-4 . i i i-2010$, leg. R. Andrade, 2 females (MZSP65734); idem, (Gruta N4E-62, 602'02"S 5009'14"W), 24-30. vii.2009, leg. R. Andrade, 1 female (MZSP-65735); idem, (Gruta N4E-85, 602'04"S 5009'27"W), 18.viii-03.ix.2009, leg. R. Andrade, 1 male (MZSP-65736); idem, (Gruta N4E-77, 601'59"S $\left.50^{\circ} 09^{\prime} 04^{\prime \prime} \mathrm{W}\right)$, 19.ii-4.iii-2010, leg. R. Andrade, 1 male (MZSP65737); idem, (Gruta N4E-89, 602'00"S 5009'08”W), 19.ii-4. iii-2010, leg. R. Andrade, 1 male (MZSP-65738); idem, (Gruta N4E-93, 602'24"S 5009'32"W), 19.ii-4.iii-2010, leg. R. Andrade, 1 male (MZSP-65739); Floresta Nacional de Carajás, Canaã dos Carajás, Pará, Brazil: (Gruta S11D-05, 6²4'04"S 50²1'01”W), 13-30.i.2010, leg. R. Andrade, 1 male (MZSP-65740); idem, (Gruta S11D-17, 6²3'57"S 50²1'24”W), 13-30.i.2010, leg. R. Andrade, 1 male (MZSP-65741); idem, (Gruta S11Cav-24, 6²4'22"S $\left.50^{\circ} 21^{\prime} 58^{\prime \prime} \mathrm{W}\right), 22-28 . i x .2010$, leg. R. Andrade, 1 male (MPEG).

Etymology. Named after the Xikrin, an indigenous tribe located about one hundred kilometers from Parauapebas, the city close to the caves where the specimens were collected. The name is a noun in apposition.

\section{Natural history of N. carajas sp. nov. and C. xikrin sp. nov.}

The specimens of both species were found in several iron ore and canga (ferruginous breccias) caves, from the entrance (photic zone) to the aphotic zone, on the ground, in areas with high moisture, under boulders, between roots, leaf litter, and in some cases near bat guano. The caves in the Serra dos Carajás, located in Eastern Amazonia (state of Pará), are composed of banded iron-formation - (BIF) from the Neoarchean. A large number of caves have been recorded in the area (more than 1,500 known caves, according to data from CeCAv 2015). Serra dos Carajás comprises a set of isolated plateaus (Fig. 21), most of which are located in the Carajás National Forest, a federally protected area that is used for different purposes, including the operation of iron ore mines. The caves where the two species described here were found are situated on scarps in different landscapes, including the edges of ponds, scarps at the top of the plateaus, and the colluvial foot slopes of ridges. The caves have developed in the inner part of the canga, within the iron ore, and at contact points between them (PILó et al. 2015). Savannah vegetation has grown on these iron crusts and particularly on top of ranges, and is surrounded by Ombrophylous Forest; in low areas out of the Carajás National Forest an altered landscape can be found. The xerophytic savannah vegetation is a singular ecosystem in the Amazon, and is known for its high level of endemism (CAmpos \& Castilho 2012). Most caves are small (<30 m long) and shallow; the trophic resources include vegetal debris, roots, and feces of vertebrates such as bats and anurans. Neither one of the two new species displays the features of typical troglobitic schizomids (e.g. elongated pedipalps, pale integument) found, for instance, in some Protoschizomus Rowland, 1975 or Agastoschizomus Rowland, 1971 (both Protoschizomidae) and Rowlandius Reddel \& Cokendolpher, 1995 (Hubbardiidae). However, it should be noted that not all troglobiotic species have troglomorphic traits (SKET 2008). Further studies should be conducted in epigean environments to confirm the degree of association of this species with hypogean habitats (see SANTOS et al. 2013). One possible troglomorphic trait, absence of eyespots, is also found in many epigean species. Only a phylogenetic hypothesis may help to determine whether such trait has evolved in response to the cave environment.

\section{ACKNOWLEDGMENTS}

We thank Osvaldo Villarreal for his very helpful comments and careful review of the manuscript and discussion on the systematics of schizomids. We are in debt with Igor Cizauskas and Marcus Oliveira for allowing us to publish photos 25 and 26, receptively. This study was supported by Vale (RPR and RA), NSF (DEB-1343612), FAPESP (BIOTA 2013/50297-0), and NASA.

\section{LITERATURE CITED}

Adis J, Reddell JR, Cokendolpher JC, Morais JW (1999) Abundance and phenology of Schizomida (Arachnida) from a primary 
upland forest in central Amazonia. Journal of Arachnology 27: 205-210.

Armas LF (2010) Schizomida de Sudamérica (Chelicerata: Arachnida). Boletin de la Sociedad Entomológica Aragonesa 46: 203-234.

Armas LF, Delgado-SANTA L (2012a) Nueva especie de Piaroa de la Cordillera Occidental de los Andes colombianos y segundo registro de Stenochrus portoricensis Chamberlin, 1922 para Colombia (Schizomida: Hubbardiidae). Boletín de la Sociedad Entomológica Aragonesa 50: 183-186.

Armas LF, Delgado-Santa L (2012b) Nuevo género de Hubbardiidae (Arachnida: Schizomida) de la Cordillera Occidental de los Andes, Colombia. Revista Ibérica de Aracnología 21: 139-143.

Campos J, Castilho AF (2012) Uma visão geográfica da Região de Carajás, p. 28-65. In: Martins FD, Castilho AF, Campos J, Hatano FM, Rolim SG (Orgs.). Fauna da Floresta de Carajás: estudos sobre vertebrados terrestres. São Paulo, Nitro Imagens.

CECAV (2015) Base de dados geoespacializados das cavernas do Brasil. Centro Nacional de Pesquisa e Conservação de Cavernas, available online at: http://www.icmbio.gov.br/ cecav/downloads/mapas.html [Accessed: 20/11/2015]

Cokendolpher JC, Reddell JR (1992) Revision of Protoschizomidae (Arachnida: Schizomidae) with notes on the phylogeny of the order. Texas Memorial Museum Speleological Monographs 3: 31-74.

Delgado-Santa L, Armas LF (2013) Tres nuevos Hubbardiinae (Schizomida: Hubbardiidae) de Colombia. Revista Ibérica de Aracnología 22: 37-45.

Harvey MS (1992) The Schizomida (Chelicerata) of Australia. Invertebrate Taxonomy 6: 77-129.

Harvey MS (2007) The smaller arachnid orders: diversity, descriptions and distributions from Linnaeus to the present (1758 to 2007). Zootaxa 1668: 363-380.

LAWRENCE RF (1969) The trichoid structures on the chelicerae of the short-tailed whip-scorpions (Schizomida; Arachnida). Transactions of the Royal Society of South Africa 38: 123-132.

Monjaraz-Ruedas R, Francke OF (2015) Taxonomic revision of the genus Mayazomus Reddell and Cokendolpher, 1995 (Schizomida: Hubbardiidae), with description of five new species from Chiapas, Mexico. Zootaxa 3915: 451-490.

Moreno-González JA, Villarreal O (2012) A new genus of Hubbardiidae (Arachnida: Schizomida) from Colombian Andes, with some taxonomic comments. Zootaxa 3560: 61-78.

Moreno-González JA, Delgado-Santa L, Armas LF (2014) Two new species of Piaroa (Arachnida: Schizomida, Hubbardiidae) from Colombia, with comments on the genus taxonomy and the flagellar setae pattern of Hubardiidinae. Zootaxa 3852(2): 227-251. doi: 10.11646/zootaxa.3852.2.4
Piló LB, Auler AS, Martins F (2015) Carajás National Forest: iron ore plateaus and caves in Southeastern Amazon, p. 273-283. In: VieIrA BC, SALGADO AAR, SANTOS LJC (Eds.). Landscapes and landforms of Brazil. Dordrecht, Springer.

Reddel JR, CoKendolpher JC (1995) Catalogue, bibliography, and generic revision of the order Schizomida (Arachnida). Texas Memorial Museum, Speleological Monographs 4: 1-170.

Rowland JM (1971) Agatochizomus lucifer, a new genus and species of cavernicole schizomid (Arachnida, Schizomida) from Mexico. Bulletin of the Association for Mexican Cave Studies 4: 13-17.

Rowland JM (1975) A partial revision of Schizomida (Arachnida), with descriptions of new species, genus, and family. Occasional Papers of the Museum, Texas Technical University 38: $1-25$

SAntos AJ, Ferreira RL, Buzatto BA (2013) Two new cave-dwellings of the short-tailed whipscorpion genus Rowlandius (Arachnida: Schizomida: Hubbardiidae) from Northeastern Brazil, with comments on male dimorphism. PloS ONE 8(5): e63616. doi: 10.1371/journal.pone.0063616

SAntos AJ, PINTO-DA-Rocha R (2009) A new micro-whip scorpion species from Brazilian Amazonia (Arachnida: Schizomida: Hubbardiidae), with the description of a new putative synapomorphy for Uropygi. Journal of Arachnology 37(1): $39-44$.

SKET B (2008) Can we agree on an ecological classification of subterranean animals? Journal of Natural History 42: 15491563. doi: $10.1080 / 00222930801995762$

Villarreal O, García LF (2012) A new species of Piaroa Villarreal, Giupponi \& Tourinho, 2008 (Schizomida: Hubbardiidae) from Colombia. Turkish Journal of Zoology 36(2): 185-189. doi: 10.3906/zoo-0907-50

Villarreal O, Armas LF, García LF (2014) A new species of Piaroa (Schizomida: Hubbardiidae) from Venezuela, with taxonomic notes on the genus. Zootaxa 3765(4): 371-381. doi: 10.11646/zootaxa.3765.4.5

Submitted: 24 November 2015

Received in revised form: 12 January 2016

Accepted: 18 January 2016

Editorial responsibility: Gabriel L.F. Mejdalani

Author Contributions: Found the new species and wrote the paper: RPR, RA. Genera and species description: RPR, RA, JMG. Made the drawings: RPR, JMG. Color pictures: RA. Made the discussion: RPR, RA, JMG.

Competing Interests: The authors have declared that no competing interests exist. 